HELMINTHOLOGIA, 53, 1: 39 - 46, 2016

\title{
Gastrointestinal parasites of the Polish primitive horses from the Biebrza National Park
}

\author{
K. SLIVINSKA ${ }^{1 *}$, Z. WRÓBLEWSKI' ${ }^{2}$ J. GAWOR ${ }^{3}$
}

\begin{abstract}
1.I. Schmalhausen Institute of Zoology, National Academy of Sciences of the Ukraine, Kyiv, vul. B. Khmelnits'kogo 15, Ukraine 01601, *E-mail: horsecez@gmail.com; ${ }^{2}$ Veterinary Private Practice, Pisz, Mickiewicza 41, Poland, E-mail: zbigwrob@op.pl; ${ }^{2} W$. Stefanski Institute of Parasitology of the Polish Academy of Sciences, Warsaw, Twarda 51/55, Poland, E-mail: gaworj@twarda.pan.pl
\end{abstract}

\section{Article info}

Received February 27, 2015 Accepted July 15, 2015

\begin{abstract}
Summary
Thirty-one Polish primitive horses (Equus caballus) from three herds (two from the reserve and one from the stable) were dewormed with ivermectin+praziquantel and examined for the gastrointestinal parasite fauna. A total of 21.231 parasites were collected from the faeces at 24,36 and 48 hours posttreatment. There were 35 nematode species, one cestode and one botfly larva. Strongyloides westeri infection was confirmed pretreatment by faecal sample examination and no threadworm specimens were found after deworming. Large and small strongyle prevalence was $90 \%-100 \%$ and represented by 31 species. Among a total of 25 cyathostome species recovered (from 19 to 24 in each group), five species (C. catinatum, C. minutus, C. longibursatus, C. nassatus and C. ashworthi) had a prevalence of $100 \%$ in three groups of horses. Meanwhile 14 species were $100 \%$ prevalent in one herd. A total of six large strongyle species were found in adult horses. Oxyuris equi was recorded in $60-100 \%$ of the horses while Parascaris equorum was detected in $100 \%$ of foals and $16.7 \%-30 \%$ of adult mares. Habronema muscae was found in $30 \%$ of the horses from one free-ranging herd. Tapeworms (Anoplocephala perfoliata) were found in $90 \%$ of the horses from one free-ranging group, whereas botfly larvae (Gasterophilus intestinalis) were found in $50-80 \%$ of all surveyed horses. The present results are compared with earlier studies of Polish primitive wild horses from similar reserves in Poland. A total of 36 gastrointestinal parasite species were recorded from wild and stabled horses from the Biebrza National Park. This is in comparison with 35 such species in free-ranging and stabled horses from the Roztocze National Park and with 28 such species of free-ranginghorses from the Popielno forest reserve.

Among parasites recovered, the highly prevalent $S$. vulgaris, tapeworms and botfly larvae pose a serious risk of serious abdominal disorders in horses.

Keywords: horse; parasite community; biodiversity; Strongylidae; Poland
\end{abstract}

\section{Introduction}

The Polish primitive horses (Equus caballus) represent a breed of domestic horses that bear a strong resemblance to tarpans, their wild ancestors which had lived on the steppes of southeastern Europe and Asia (Western Siberia). The original breed was com- pletely extinct by the end of the $19^{\text {th }}$ century. In the mid-twentieth century, primitive horses exhibiting tarpans' exterior were found in small farms of eastern Poland and saved in the reserve as the Polish primitive horses, a subspecies of tarpans. Currently, there are four reserves in Poland in which these horses are being kept in natural conditions. The horses are perfectly adapted to the natu- 
ral environment and climate where they live throughout the year. Polish primitive horses are kept in Biebrza National Park (BNP), situated in the valley of the Biebrza River in northeastern Poland since 2004. The habitat of horses embraces 200 hectares of forest, grassland and marsh places, currently occupied by two herds (10 and 11 horses each). For veterinary and zootechnical control, all free-ranging horses are captured in the reserve during November - December. No anthelmintic treatment has been applied to date to these horses.

Despite the fact that Polish primitive horses are well known for their strong disease resistance, parasitic infections may influence their health. Until now the investigations of parasitic fauna in Polish primitive horses were performed in the Popielno Forest Reserve in northeastern Poland (Slivinska et al., 2009) and the Roztocze National Park in southeastern Poland (Slivinska et al., 2013). There are no data available on the gastrointestinal parasite community of horses from the Biebrza National Park.

The aim of this study was to investigate the gastrointestinal parasite community structure in previously untreated Polish primitive horses in the Biebrza National Park, and compare these results with those previously obtained in free-ranging horses from two other natural reserves.

\section{Material and Methods}

\section{Horses}

In this study 31 horses were examined. Twenty-one from the Biebrza National Park free-ranging (Group I and II) and 10 stabled horses (Group III) from the area next to the BNP. Group I consisted of 10 horses ( 1 stallion 6 years old, 6 mares $4-6$ years old, 3 offspring 6 months old). Group II was comprised of 11 horses ( 1 stallion 8 years old, 10 mares 2 - 6 years old). Group II was transported from the National Park "Seven Islands" and kept under quarantine in a paddock for 9 months in Biebrza National Park until the present study. No anthelminthic treatment had been applied to the wild horses from Group I and II previously. Group III has been kept under stabled management on a private farm in the area next to the BNP. This group consisted of 1 gelding ( 5 years old), 6 mares ( $4-6$ years old) and 3 offspring ( $6-10$ months old). The horses were kept in a stable at night and returned to fenced pastures during the day. They have been dewormed irregularly, once or twice a year.

\section{Faecal egg counting}

Faecal egg counts were carried out on the day before treatment using the McMaster technique (Herd, 1992) with a sensitivity of 25 eggs per gram (EPG). EPG values were counted individually for each horse and calculated for each group (Table 1).

Worm burden and species identification

All horses $(n=31)$ were treated with ivermectin $(18.7 \mathrm{mg})+$ praziquantel (140.3 mg) (Equimax paste, Virbac de Portugal Labora- torios) in a dose of $1.07 \mathrm{~g}$ paste per $100 \mathrm{~kg}$ b.w. Faecal sampling for the expelled parasites ( $200 \mathrm{~g}$ of faeces in each sample) was performed for each animal per rectum 24, 36 and 48 hours posttreatment. The samples were washed with tap water into a glass cylinder and the sediment preserved in $40 \%$ alcohol.

The mean worm burden (total number of worm specimens per sample) was calculated for each parasite species. The total number for each individual parasite species $(\mathrm{N})$ was calculated as

$$
\mathrm{N}=\left(\frac{W f}{200}\right) \times \mathrm{N}_{\mathrm{s}},
$$

where $W_{f}$ is the total faeces weight produced by the horse during the experiment and $N_{s}$ is the mean number of worm individuals in all samples collected from the horse. Based on these data the mean worm burden was calculated for each parasite species (Kuzmina et al., 2005).

In the laboratory the gastrointestinal parasites were isolated, fixed in $70 \%$ alcohol, counted and identified to the species level using the key of Lichtenfels et al., (2008).

\section{Statistical analyses}

Data summaries and descriptive analyses were calculated with Microsoft ${ }^{\mathrm{TM}}$ Excel.

To characterize the species diversity of parasites, we used the Shannon-Wiener index: $H^{\prime}=-\Sigma n_{i} / N \log _{2} n_{i} / N$, where $n_{i}$ is the population density of each of the species and $\mathrm{N}$ is the overall density of populations (Shannon \& Weaver, 1949).

The similarities in the species composition of parasites in different groups of horses were estimated using the Chekanovsky-Sørensen index of similarity $\left(\mathrm{I}_{C S}\right)$ (Pesenko, 1982). $\mathrm{I}_{C S}=2 \mathrm{a} /(\mathrm{a}+\mathrm{b})+(\mathrm{a}+\mathrm{c})$, where $a$ is the number of common species and $(a+b)+(a+c)$ is the arithmetic mean of the number of species in both lists under comparison.

\section{Results}

\section{Overall findings}

A total of 21.231 parasite specimens were recovered from 31 horses and identified to the species level. The expelled parasites represented 36 species, i.e. 25 small strongyle species, 6 large strongyle species and by one species of ascarid, oxyurid, habronematid, cestode and botfly larvae (Table 2 and 3). In addition, threadworm infection (Strongyloides westeri) was confirmed in four foals by faecal sample examination (Table 1).

The total number of parasites expelled per horse varied from 37 to 1.124 with an average of $686.3 \pm 417.7$. Positive correlation was observed between the EPG value of ascarids and the total number collected from faeces $\left(r^{2}=0.92, P<0.01\right)$. A negative correlation was observed between the EPG value of strongylides and the total number of strongylid worm collected $\left(r^{2}=-0,17, P<0.01\right)$. 
Table 1. Results of faecal egg counts in free-ranging and stabled Polish primitive horses ( $n=31)$ in the Biebrza National Park, Poland

\begin{tabular}{|c|c|c|c|c|c|c|c|c|c|c|c|}
\hline \multirow[t]{2}{*}{ Horses } & & \multicolumn{3}{|c|}{ Strongylidae } & \multicolumn{3}{|c|}{ Parascaris equorum } & \multicolumn{3}{|c|}{ Strongyloides westeri } & \multirow[t]{2}{*}{ Cestoda } \\
\hline & & El \% & Mean EPG & SD & El \% & MeanEPG & SD & $\mathrm{El} \%$ & MeanEPG & $\mathrm{SD}$ & \\
\hline \multirow{3}{*}{$\begin{array}{c}\text { Group I, } \\
n=10\end{array}$} & Stallion, $n=1$ & 100 & 1425.0 & 0 & 0 & 0 & 0 & 0 & 0 & 0 & 0 \\
\hline & Mares, $n=6$ & 100 & 1087.5 & 412.5 & 16.7 & 50 & 0 & 0 & 0 & 0 & 0 \\
\hline & Foals $n=3$ & 100 & 1025.0 & 327.9 & 100 & 566.7 & 454.4 & 100 & 150 & 86.6 & 0 \\
\hline \multirow{3}{*}{$\begin{array}{c}\text { Group II, } \\
n=11\end{array}$} & Stallion, $n=1$ & 100 & 75.0 & 0 & 0 & 0 & 0 & 0 & 0 & 0 & 0 \\
\hline & Mares, $n=10$ & 100 & 750.0 & 404.1 & 0 & 0 & 0 & 0 & 0 & 0 & 0 \\
\hline & Geld, $n=1$ & 100 & 575 & 0 & 0 & 0 & 0 & 0 & 0 & 0 & 0 \\
\hline \multirow{2}{*}{$\begin{array}{c}\text { Group III, } \\
n=10\end{array}$} & Mares, $n=6$ & 100 & 529.2 & 389.0 & 16.7 & 25 & 0 & 0 & 0 & 0 & 0 \\
\hline & Foals, $n=3$ & 100 & 541.7 & 278.8 & 100 & 236.7 & 162.5 & 33.3 & 400 & 0 & 0 \\
\hline
\end{tabular}

EPG - eggs per gram

El, \% - prevalence

A total of six large strongyle species was found in adult horses from three groups. Regarding the horses from the reserves, Strongylus vulgaris and S. edentatus were the most prevalent $(57.1 \%$ $-72.7 \%$ and $85.7 \%-90.9 \%$, respectively) and Triodontophorus serratus, T. brevicauda, T. tenuicollis and Craterostomum acuticaudatum were quite common $(36.4 \%-54.6 \%)$. In adult wild horses, 7.5 and 5.0 specimens of Strongylus vulgaris and S. edentatus were found, respectively. Only one specimen of $T$. serratus and T. tenuicollis was recorded in adult horses (Table 2).

Small strongyles occurred in all horses and were the most abundant among gastrointestinal parasites. Among a total of 25 cyathostome species found, eight (Cyathostomum catinatum, Coronocyclus coronatus, Cylicostephanus calicatus, C. minutus, C. longibursatus, Cylicocyclus insigne, Cylicocyclus nassatus and C. ashworthi) were $90-100 \%$ prevalent in the three herds and constitute the bulk of the parasite community in surveyed horses (Table 2). The mean worm burden of cyathostomes per horse ranged from single specimens of a rare species (Cylicocyclus radiatus and Gyalocephalus capitatus) found in the prevalence of $10 \%-27.3 \%$, up to $21.4-170.2$ specimens to the five $100 \%$ prevalent species (Cyathostomum catinatum, Cylicostephanus minutus, C. longibursatus, Cylicocyclus nassatus, C. ashworthi). The prevalence of Parascaris equorum was $100 \%$ in foals kept in the reserve and $16.7 \%-30 \%$ in free-ranging and stabled mares. Oxyuris equi and botfly larvae (Gasterophilus intestinalis) were the most common non-strongylid parasites in horses, with prevalence $60-100 \%$ and $50-80 \%$, respectively. The mean number of ascarids per horse was $9.0 \pm 4.2$, oxyurids $6.1 \pm 4.8$ and habronematids $1.0 \pm 0.5$ (Table 2).

Gastrointestinal parasite community in Group I $(n=10)$

Results of faecal egg counts are provided in Table 1. The mean epg for strongylids was 1,102.2 (ranging from 75 to 1,725 ). Three foals were found to be infected with ascarids. The mean epg was 566.7. $P$. equorum eggs also were excreted by one mare. The foals were infected with Strongyloides westeri (a mean epg 150).
Thirty-three species of gastrointestinal parasites were recovered after deworming. Among all 31 nematode species, 28 were Strongylidae and one species from Oxyuridae, Ascaridae and Habronematidae. One cestode (Anoplocephala perfoliata) and one species of botfly larvae (Gasterophilus intestinalis) also were found (Table 2). Nine to 25 parasite species were found per host (a mean 18.1) where four strongyle and 24 cyathostome species were recorded.

In adult horses, four large strongyle species (S. vulgaris, S. edentatus, T. serratus and T. tenuicollis) were found. Strongylus vulgaris and S. edentatus were of the highest prevalence (57.1 - $85.7 \%$ ). Small strongyles (Cyathostominae) were represented by 24 species. Among them nine species (Cyathostomum catinatum, C. pateratum, Coronocyclus coronatus, Cylicostephanus calicatus, C. minutus, C. longibursatus, Cylicocyclus nassatus, C. ashworthi and $C$. insigne) were $90-100 \%$ prevalent.

Oxyuris equi and botfly larvae ( $G$. intestinalis) were recorded in $70-80 \%$ horses, while Parascaris equorum and Habronema muscae in $20 \%-30 \%$, respectively. Tapeworms (Anoplocephala perfoliata) were found in $90 \%$ of the horses (Table 2).

Generally, the number of parasite specimens recovered from the surveyed horses was low. The mean number of large strongyle specimens varied from $1.0-7.5$ per host, with the highest numbers for $S$. vulgaris and $S$. edentatus (a mean 5.0 - 7.5 per host). The nine cyathostome species recorded as $90-100 \%$ prevalent. The mean number of specimens recovered ranged from 8.7 (C. insigne) to 72.0 (C. nassatus).

The mean number per horse for ascarids was 9.0 , oxyurids 6.1 , habronematids 1.0 and cestodes 4.1. One non-helminth gastrointestinal parasite, a botfly larvae ( $G$. intestinalis), was recorded with the prevalence of $80 \%$ and intensity of $2-12$ instars per horse (a mean 4.4).

No threadworm specimens were recovered after deworming in foals despite detection of 150 S. westeri eggs per gram of faecal samples isolated from three animals. 
Table 2. Results of the gastrointestinal survey in free-ranging and stabled Polish primitive horses $(n=31)$ in the Biebrza National Park, Poland

\begin{tabular}{|c|c|c|c|c|c|c|c|c|c|c|}
\hline \multirow{3}{*}{ Parasite species } & \multicolumn{4}{|c|}{ Group I $(n=10)$} & \multicolumn{2}{|c|}{ Group II (n=11) } & \multicolumn{4}{|c|}{ Group III $(n=10)$} \\
\hline & \multicolumn{2}{|c|}{ Prevalence \% } & \multicolumn{2}{|c|}{$\begin{array}{c}\text { MWB } \pm \text { SD } \\
\text { (Total number of } \\
\text { specimens) }\end{array}$} & \multirow{2}{*}{$\begin{array}{c}\text { Prevalence \% } \\
\begin{array}{c}\text { Adults horses, } \\
n=11\end{array}\end{array}$} & \multirow[t]{2}{*}{$\begin{array}{c}\text { MWB } \pm \text { SD } \\
\text { (Total number of } \\
\text { specimens) }\end{array}$} & \multicolumn{2}{|c|}{ Prevalence \% } & \multicolumn{2}{|c|}{$\begin{array}{c}\text { MWB } \pm \text { SD } \\
\text { (Total number } \\
\text { of specimens) }\end{array}$} \\
\hline & $\begin{array}{c}\text { Adults } \\
\text { horses, } \\
n=7\end{array}$ & $\begin{array}{c}\text { Foals, } \\
n=3\end{array}$ & $\begin{array}{c}\text { Adults } \\
\text { horses, } \\
n=7\end{array}$ & $\begin{array}{c}\text { Foals, } \\
n=3\end{array}$ & & & $\begin{array}{c}\text { Adults } \\
\text { horses, } \\
n=7\end{array}$ & $\begin{array}{c}\text { Foals, } \\
n=3\end{array}$ & $\begin{array}{c}\text { Adults } \\
\text { horses, } \\
n=7\end{array}$ & $\begin{array}{c}\text { Foals, } \\
n=3\end{array}$ \\
\hline Strongylinae & 60 & & $6.3(63)$ & & 100 & $\begin{array}{c}17.2 \\
(189)\end{array}$ & 30 & & $6.3(19)$ & \\
\hline Strongylus vulgaris & 57.1 & 0 & $7.5 \pm 5.5$ & 0 & 72.7 & $8.0 \pm 5.6$ & 28.6 & 0 & $3.0 \pm 1.6$ & 0 \\
\hline S. edentatus & 85.7 & 0 & $5.0 \pm 4.1$ & 0 & 90.9 & $9.1 \pm 5.5$ & 28.6 & 0 & $5.5 \pm 2.7$ & 0 \\
\hline Triodontophorus serratus & 28.6 & 0 & $1 \pm 0.5$ & 0 & 54.6 & $2.0 \pm 1.3$ & 0 & 0 & 0 & 0 \\
\hline T. brevicauda & 0 & 0 & 0 & 0 & 45.5 & $2.0 \pm 1.1$ & 14.3 & 0 & $2.0 \pm 0.8$ & 0 \\
\hline T. tenuicollis & 14.3 & 0 & $1 \pm 0.4$ & 0 & 36.6 & $1.5 \pm 0.8$ & 0 & 0 & 0 & 0 \\
\hline Craterostomum acuticaudatum & 0 & 0 & 0 & 0 & 36.4 & $1.5 \pm 0.8$ & 0 & 0 & 0 & 0 \\
\hline Cyathostominae & 100 & & 312.2 & & 100 & $982.7(10810)$ & 100 & & $63.9(6$ & \\
\hline Cyathostomum catinatum & 100 & & $57.4 \pm$ & & 100 & $137.2 \pm 26.9$ & 100 & & $115.6 \pm$ & 90.9 \\
\hline C. pateratum & 90 & & $12.4 \pm$ & & 100 & $22.9 \pm 10.1$ & 70 & & $23.1 \pm$ & \\
\hline Coronocyclus coronatus & 100 & & $14.7 \pm$ & & 100 & $47.0 \pm 19.9$ & 90 & & $37.6 \pm$ & 8.1 \\
\hline C. labiatus & 50 & & $2.4 \pm$ & & 100 & $9.6 \pm 4.2$ & 60 & & $10.3 \pm$ & \\
\hline C. labratus & 50 & & $3.8 \pm$ & & 100 & $10.6 \pm 3.4$ & 60 & & $7.2 \pm$ & \\
\hline Cylicostephanus calicatus & 90 & & $15.4 \pm$ & & 100 & $50.7 \pm 21.3$ & 100 & & $22.8 \pm$ & 18.4 \\
\hline C. minutus & 100 & & $44.6 \pm$ & & 100 & $158.5 \pm 52.7$ & 100 & & $115.6 \pm$ & 88.0 \\
\hline C. hybridus & 30 & & $1.0 \pm$ & & 45.5 & $1.6 \pm 0.9$ & 0 & & 0 & \\
\hline C. longibursatus & 100 & & $51.5 \pm$ & & 100 & $166.7 \pm 27.5$ & 100 & & $104.6 \pm$ & 81.3 \\
\hline C. goldi & 80 & & $8.4 \pm$ & & 100 & $30.0 \pm 10.4$ & 90 & & $25.6 \pm$ & \\
\hline C. bidentatus & 30 & & $1.0 \pm$ & & 72.7 & $2.1 \pm 1.3$ & 10 & & $2.0 \pm$ & \\
\hline Cylicocyclus radiatus & 10 & & $1.0 \pm$ & & 27.3 & $1.0 \pm 0.5$ & 0 & & 0 & \\
\hline C. elongatus & 70 & & $2.4 \pm$ & & 100 & $16.3 \pm 4.8$ & 90 & & $16 \pm$ & \\
\hline C. insigne & 90 & & $8.7 \pm$ & & 100 & $44.3 \pm 19.9$ & 100 & & $20.3 \pm$ & 6.1 \\
\hline C. leptostomum & 80 & & $4.8 \pm$ & & 100 & $18.7 \pm 6.3$ & 60 & & $13.8 \pm$ & \\
\hline C. nassatus & 100 & & $72.0 \pm$ & & 100 & $170.2 \pm 43.3$ & 100 & & $111.3 \pm$ & 85.9 \\
\hline C. ashworthi & 100 & & $21.4 \pm$ & & 100 & $86.6 \pm 23.1$ & 100 & & $38.2 \pm$ & \\
\hline C. ultrajectinus & 30 & & $1.0 \pm$ & & 72.7 & $4.5 \pm 3.9$ & 20 & & $2.0 \pm$ & \\
\hline Cylicodontophorus bicoronatus & 10 & & $1.0 \pm$ & & 63.6 & $3.1 \pm 2.2$ & 0 & & 0 & \\
\hline Parapoteriostomum euproctus & 40 & & $2.0 \pm$ & & 0 & 0 & 40 & & $5.5 \pm$ & \\
\hline P. mettami & 10 & & $1.0 \pm$ & & 72.7 & $2.5 \pm 1.5$ & 50 & & $1.4 \pm$ & \\
\hline Poteriostomum imparidentatum & 10 & & $1.0 \pm$ & & 63.6 & $1.9 \pm 1.2$ & 0 & & 0 & \\
\hline P. ratzii & 10 & & $1.0 \pm$ & & 54.6 & $2.0 \pm 1.3$ & 0 & & 0 & \\
\hline Petrovinema poculatum & 20 & & $1.0 \pm$ & & 81.8 & $1.6 \pm 0.9$ & 30 & & $1.3 \pm$ & \\
\hline G. capitatus & 0 & & 0 & & 27.3 & $1.0 \pm 0.5$ & 0 & & 0 & \\
\hline \multicolumn{11}{|l|}{ Ascaridae } \\
\hline Parascaris equorum & 20 & & $\begin{array}{r}9.0 \pm \\
\quad(18\end{array}$ & & 0 & 0 & 30 & & $\begin{array}{r}2.0 \pm \\
(6\end{array}$ & \\
\hline
\end{tabular}




\begin{tabular}{|c|c|c|c|c|c|c|}
\hline \multicolumn{7}{|l|}{ Oxyuridae } \\
\hline Oxyuris equi & 70 & $\begin{array}{c}6.1 \pm 4.8 \\
(43)\end{array}$ & 100 & $\begin{array}{c}39.6 \pm 12.5 \\
(435)\end{array}$ & 60 & $\begin{array}{c}2.0 \pm 1.6 \\
(12)\end{array}$ \\
\hline \multicolumn{7}{|l|}{ Habronematidae } \\
\hline Habronema muscae & 30 & $\begin{array}{c}1.0 \pm 0.5 \\
(3)\end{array}$ & 0 & 0 & 0 & 0 \\
\hline \multicolumn{7}{|l|}{ Anoplocephalidae } \\
\hline Anoplocephala perfoliata & 90 & $\begin{array}{c}4.1 \pm 2.0 \\
(37)\end{array}$ & 0 & 0 & 0 & 0 \\
\hline \multicolumn{7}{|l|}{ Gasterophilidae } \\
\hline Gasterophilus intestinalis & 80 & $\begin{array}{c}4.4 \pm 3.4 \\
(35)\end{array}$ & 72.7 & $5.8 \pm 3.3(46)$ & 50 & $\begin{array}{c}2.4 \pm 1.5 \\
(12)\end{array}$ \\
\hline
\end{tabular}

MWB - mean worm burden; SD - standard deviation

Gastrointestinal parasite community in Group /I $(n=11)$

This herd consisted of adult horses only. Based on faecal egg count results (Table 1), all horses were infected with strongylids and no other parasite eggs were found. Among all 32 species recovered, 31 were nematode species (30 strongyle and one oxyurid) and one species of botfly larvae (Table 2). Twenty to 28 species were found per host (a mean 24.9) where six strongyle and 24 cyathostome species were recorded. Among large strongyles found, $S$. vulgaris and $S$. edentatus were the most prevalent (72.7 \% and $90.9 \%$, respectively) and the three species of Triodontophorus were quite common (36.6 - 54.6\%). Fourteen small strongyle species (C. catinatum, C. pateratum, C. coronatus, $C$. labiatus, C. labratus, C. calicatus, C. minutus, C. longibursatus, $C$. goldi, $C$. elongatus, $C$. insigne, $C$. leptostomus, $C$. nassatus and $C$. ashworthi) were $90-100 \%$ prevalent (Table 2).

The mean number of large strongyles was $1.5-9.1$ and of the most common small strongyle species ranged from 9.6 (C. labiatus) to 170.2 (C. nassatus) per horse. Oxyuris equi was found to have a mean of 39.6 specimens per horse. Botfly larvae (G. intestinalis) were recorded in $72.7 \%$ of horses with $2-9$ specimens found per horse (a mean 5.8).

\section{Gastrointestinal parasite community in Group III $(n=10)$}

Based on faecal egg counts, all horses were infected with strongylids (529 - 575 epg) and one mare and three foals were infected with ascarids (Table 1). One foal was infected with Strongyloides westeri (a mean $400 \mathrm{epg}$ ); however no threadworm specimens were recovered after deworming this foal.

In total, 26 gastrointestinal parasite species were found in stabled horses, i.e. 25 were nematodes and one species was a botfly larva (Table 2 and 3). Ten to 21 species with a mean of 15.6 per host were found. Three large strongyle species (S. vulgaris, S. edentatus and T. brevicauda) were $14.3-28.6 \%$ prevalent. This was similar to Group I from the reserve where large strongyles were detected only in adult horses. Among a total 19 cyathostome species recorded, ten were $90-100 \%$ prevalent (C. catinatum, C. coronatus, $C$. calicatus, C. minutus, C. longibursatus, C. goldi, C. elongatus, $C$. insigne, $C$. nassatus and $C$. ashworthi). Oxyuris equi, Parascaris equorum and botfly larvae (G. intestinalis) were found in $60 \%$,
$30 \%$ and $50 \%$ of horses, respectively (Table 2 ).

In general, the number of gastrointestinal parasites recovered from the stabled horses was low. Means of 3.0 to 5.5 specimens of $S$. vulgaris and S. edentatus were found and 20.3 (C. insigne) to 115.6 (C. minutus and $C$. catinatum) of the ten most common cyathostome species recovered (Table 2). The prevalence of ascarids and oxyurids was $30 \%$ and $60 \%$, respectively. Mean of 2.0 specimens was found per horse after deworming. Gasterophilus intestinalis larvae were recorded in $50.0 \%$ of the horses for which 1 - 4 specimens were found (a mean 2.4).

\section{Biodiversity approach}

Species richness of the parasite community was much higher in free-ranging horses kept under natural conditions (Group I and II) when compared with stabled horses (Group III). The results of the multivariate analyses of the parasite community showed the significant differences of the Shannon-Wiener diversity indices for the parasite community in wild horses from Group II and I $\left(\mathrm{H}^{\prime}=\right.$ 2.499 and 2.381, respectively), when compared with communities of stabled horses from Group III ( $\left.\mathrm{H}^{\prime}=2.285\right)$.

Biodiversity of the parasite communities of wild horses from Group I and II are rather similar. The Chekanovsky-Sørenses Index $\left(I_{c-s}\right)$ is 0.89 . Species richness of the parasite communities in horses from Group I and III is more similar $\left(\mathrm{I}_{\mathrm{c-s}}=0.83\right)$ than in horses from Group II and III $\left(I_{c-s}=0.81\right)$.

\section{Discussion}

The results presented herein are the first in vivo comparative investigations of parasite communities in free-ranging and stabled horses in Poland. The effectiveness of intravital collection of intestinal helminthes was shown to provide data comparable with those based on postmortem methods (Osterman Lind et al., 2003; Kuzmina et al., 2005).

Only one infection (Strongyloides westeri) was not confirmed with diagnostic deworming but was defined by presence of eggs in faeces of three foals from one free-ranging herd and one foal from the stable. Despite a mean of 150 and 400 eggs per gram in faecal samples, no threadworm specimens were recovered af- 
Table 3. The gastrointestinal parasite species found in Polish primitive horses from Biebrza National Park (present study), Roztocze National Park (Slivinska et al., 2013) and Popielno forest reserve (Slivinska et al., 2009)

\begin{tabular}{|c|c|c|c|c|c|c|}
\hline \multirow[t]{3}{*}{ Parasite species } & \multicolumn{3}{|c|}{ Present study } & \multirow{3}{*}{$\begin{array}{c}\text { Roztocze } \\
\text { Wild horses, } n=16 \\
\text { (Slivinska et al. 2013) }\end{array}$} & \multirow{3}{*}{$\begin{array}{c}\text { Roztocze } \\
\text { Stabled horses, } n=13 \\
\text { (Slivinska et al. 2013) }\end{array}$} & \multirow{3}{*}{$\begin{array}{c}\text { Popielno } \\
\text { Wild horses, } n=11 \\
\text { (Slivinska et al. 2009) }\end{array}$} \\
\hline & \multicolumn{2}{|c|}{ Wild horses, n=21 } & \multirow{2}{*}{ Stabled horses, $n=10$} & & & \\
\hline & Group I & Group II & & & & \\
\hline Strongylus vulgaris & + & + & + & + & + & + \\
\hline S. edentatus & + & + & + & + & + & - \\
\hline Triodontophorus serratus & + & + & - & + & + & + \\
\hline T. brevicauda & - & + & + & + & + & - \\
\hline T. tenuicolis & + & + & - & + & + & - \\
\hline Craterostomum acuticaudatum & - & + & - & + & + & - \\
\hline Cyathostomum catinatum & + & + & + & + & + & + \\
\hline C. pateratum & + & + & + & + & + & + \\
\hline Coronocyclus coronatus & + & + & + & + & + & + \\
\hline C. labiatus & + & + & + & + & + & + \\
\hline C. labratus & + & + & + & + & + & + \\
\hline Cylicostephanus calicatus & + & + & + & + & + & + \\
\hline C. minutus & + & + & + & + & + & + \\
\hline C. hybridus & + & + & - & + & - & - \\
\hline C. longibursatus & + & + & + & + & + & + \\
\hline C. goldi & + & + & + & + & + & + \\
\hline C. bidentatus & + & + & + & + & - & + \\
\hline Cylicocyclus radiatus & + & + & - & + & - & - \\
\hline C. elongatus & + & + & + & + & + & + \\
\hline C. insigne & + & + & + & + & + & + \\
\hline C. leptostomus & + & + & + & + & + & + \\
\hline C. nassatus & + & + & + & + & + & + \\
\hline C. ashworthi & + & + & + & + & + & + \\
\hline C. ultrajectinus & + & + & + & + & - & + \\
\hline C. bicoronatus & + & + & - & + & - & + \\
\hline C. euproctus & + & - & + & + & + & + \\
\hline C. mettami & + & + & + & + & + & + \\
\hline Poteriostomum imparidentatum & + & + & - & + & + & + \\
\hline P. ratzii & + & + & - & + & - & - \\
\hline Petrovinema poculatum & + & + & + & + & + & - \\
\hline Gyalocephalus capitatus & - & + & - & + & - & + \\
\hline Parascaris equorum & + & - & + & + & + & + \\
\hline Habronema muscae & + & - & - & + & + & + \\
\hline Oxyuris equi & + & + & + & - & - & + \\
\hline Anoplocephala perfoliata & + & - & - & + & + & + \\
\hline Gasterophilus intestinalis & + & + & + & + & + & + \\
\hline Number of cyathostome species & 24 & 24 & 19 & 25 & 18 & 21 \\
\hline Number of parasite species & 33 & 32 & 25 & 35 & 28 & 28 \\
\hline
\end{tabular}

ter deworming. Possibly it was the result of low infection intensity or the worms may have been overlooked during examination for expelled parasites. These nematodes have a very thin cuticle and thus probably specimens passed out disintegrated. Moreover, they could have been digested during their transfer from the intestine to the rectum and passed in the faeces.

The present results are similar to those obtained in the earlier surveys in the Polish primitive horses living in the free-ranging conditions (Slivinska et al., 2009, 2013). A total of 37 gastro-intestinal parasite species were recorded in wild and stabled horses from the BNP in comparison with 35 such species in horses from the Roztocze National Park (Slivinska et al., 2013) and 28 species in wild yearlings from the Popielno Forest Reserve (Slivinska et al., 2009) - Table 3. Among a total of 25 cyathostome species recovered in the current study (from 19 to 24 in one group), five species (C. catinatum, C. minutus, $C$. longibursatus, $C$. nassatus and $C$. ashworthi) were of $100 \%$ prevalence in three herds, while 14 species were $100 \%$ prevalent in at least one group. We found the same 25 small strongyle species in horses from two wild herds as in the Roztocze National Park reserve (Slivinska et al., 2013). In the present study we examined horses that were not dewormed previously, which suggested that there might exist a rich parasite fauna. Kuzmina et al., (2008). The study aimed to evaluate the influence of anthelmintic treatments on strongylid community struc- 
ture based on the hypothesis that regular anthelmintic treatments cause a reduction of species richness, diversity and concentration in strongylid communities. These parameters were significantly higher in cyathostome communities of horses from nontreated and occasionally treated horses than in regularly treated horses. The strongylid communities of wild equids or equids from natural reserves are characterized by multimodal distribution of species, with dominant, subdominant, background and rare species (Kuzmina et al., 2008). Some cyathostome species found dominant or subdominant in the wild Polish horses in the present study and in the previous surveys, have been recorded as background or rare/very rare species in brood horses in Poland. Cylicostephanus bidentatus, fairly prevalent in this study in horses from the reserve (30\% and $72.7 \%$ ), also was found in one horse from the stabled group (10\%). This cyathostome species recorded in $27.3 \%$ of yearlings in the Popielno Forest Reserve, was the first occurrence in the horse in Poland (Slivinska et al., 2009). Cyathostome species, with $9.1 \%$ prevalence, were rare in yearlings from Popielno (Poteriostomum imparidentatum and Parapoteriostomum metta$\mathrm{mi}$ ), while Poteriostomum ratzii and Petrovinema poculatum were not recorded in these horses. The present study showed these four species being subdominant or dominant $(54.6-81.8 \%)$ in horses from one free-ranging herd (Group II). For comparison, the prevalence of these species in working horses examined after slaughter in central Poland was $2 \%, 8 \%, 10 \%$ and $20 \%$ for $P$. ratzii, $P$. poculatum, $P$. mettami and $P$. imparidentatum, respectively (Gawor 1995). More recent survey in irregularly dewormed domestic horses from southern Poland (Kuzmina et al., 2011) revealed P. poculatum, P. mettami and P. imparidentatum,

Regarding four cyathostome species, namely Cylicostephanus hybridus, Cylicocyclus radiatus, Poteriostomum ratzii and Gyalocephalus capitatus found in the group I and/or the group II (10 - $45.5 \%$ ) and also recorded in the wild horses from Roztocze Park, neither of them were revealed in stabled horses in the current study, and nor in such horses from Roztocze Park (Table 2 and 3). These horses occasionally were dewormed, which possibly eliminated the presence of these rare/background species. However, even under frequent anthelmintic treatments, dominant species are still present in the strongylid community (Kuzmina et al., 2008). The present findings that a few cyathostome species constitute the bulk among strongylids in the wild horses are similar to results of surveys conducted in various breeds of horses in different countries, i.e. Poland and Ukraine (Gawor 1995; Kuzmina et al., 2011), Spain (Meana et al., 2004), United States (Reinemeyer et al., 1984; Lyons et al., 1997), South Africa (Scialdo-Krecek et al., 1983) and Australia (Mfitilodze \& Hutchinson 1990). In the present study, 9 cyathostome species found in horses from Group I, 14 species from Group II and 10 species from Group III were 90 - $100 \%$ prevalent and comprised $92.5-96.9 \%$ of the strongyle population representing $89.8-93.2 \%$ of the total parasites recovered in each group.

In general, surveyed horses from BNP, Roztocze and Popielno with the high helminth diversity were associated with low intensity of infection. The mean number of cyathostome specimens in the current study was $1.0-170.2$ and $1.0-134.7$ and $1.3-166.1$ in Roztocze and Popielno, respectively. Concerning large strongyle species, the mean number in the present study was $1.0-9.1$ and 1.5 - 11.0 in Roztocze or 1.9 - 2.5 in Popielno (Slivinska et al., 2009, 2013).

We found the same six large strongyle species in two groups from the BNP reserve, similar to the wild horses from the Roztocze National Park. In the current study no large strongyle infection was found in the six foals examined. These results differ from the previous results found in 11 yearlings captured in the Popielno Reserve in which S. vulgaris and Triodontophorus serratus were found; the prevalence was $81.8 \%$ and $90.9 \%$, respectively (Slivinska et al., 2009). These differences may be due to the younger foals' age in the current study (6 - 10 months) when compared to those examined in the Popielno Reserve (12 - 14 months). On the whole, in wild horses from the recently examined reserves, Roztocze and Popielno, S. vulgaris and S. edentatus were highly prevalent, $57.1 \%-93.8 \%$ and $81.3 \%-85.7 \%$, respectively. Two recent surveys in rarely dewormed horses from individual farms in southeastern Poland revealed these species had prevalences of $4 \%$ for each species (Kuzmina et al., 2011) and $22.8 \%$ and $18.3 \%$, respectively (Studzińska et al., 2012). Recent studies from different countries have shown that in well managed horse populations, $S$. vulgaris have become uncommon among equine parasites. Increased occurrence of this most pathogenic parasite infecting horses, has recently been associated with the widely recommended selective therapy approach for parasite control (Nielsen et al., 2012). Reduced treatment intensities, with the general approach to leave untreated horses with a low egg count value (selective therapy), potentially delays development of ivermectin and moxidectin resistance in cyathostomes and ascarids. This approach to leave horses with low egg counts (selective therapy) untreated, may be a possible reason of an increased prevalence of $S$. vulgaris in stud farms and training stables (Nielsen et al., 2012).

The present and previous surveys in the wild Polish primitive horses from the reserves in Poland, confirmed that these horses represent populations from the pretreatment era with parasite fauna not influenced by deworming practices. Large strongyle species richness with the high prevalence of $S$. vulgaris and $S$. edentatus, seems to be proof of this assumption.

The prevalence of pinworms (Oxyuris equi) in horses in three examined herds in the current study $(60-100 \%)$ was higher than in yearlings from the Popielno Forest Reserve $(23.1 \%)$ (Slivinska et al., 2009). No oxyurids were recovered in horses from the Roztocze National Park (Slivinska et al., 2013). The prevalence of Parascaris equorum in adult mares was $16.7 \%-30 \%$ which is similar to that found in mares from Roztocze $(15.4 \%-25.0 \%)$. Habronema muscae specimens with $30 \%$ prevalence were recorded in one group of wild horses which is similar to results from Roztocze and Popielno (55.2 \% and $18.2 \%$, respectively). Ano- 
plocephala perfoliata with prevalence of $90 \%$, was found in one wild herd. This was similar to a level found in Roztocze (72.2\%), meanwhile in Popielno, $24.2 \%$ of yearlings were found infected with tapeworms. The prevalence of the botfly larvae (Gasterophilus intestinalis) was $50-80 \%$, which is different from their occurrence in wild horses in Popielno (90.9 \%) and Roztocze (41.4\%) (Slivinska et al., 2009, 2013).

\section{Conclusions}

Among the major parasitic pathogens in horses, cyathostomins, $P$. equorum, $A$. perfoliata and $S$. vulgaris are mentioned. Along with $G$. intestinalis having the potential for serious abdominal disorders, all these parasites were found at high prevalences in wild horses examined in the present study. Reliable detection and differentiation of these parasites is an important requirement for diagnostics in equine parasitology. Diagnostic deworming, used with collection and identification of expelled parasites to the species level, is laborious method. However, it provides detailed information on prevalence and intensity of gastro-intestinal parasite infection, including tapeworms whose eggs are specifically difficult to detect by fecal examination. The wild horses living freely in the reserve and not treated previously with anthelmintics, represent exceptional hosts for investigation of the horse primeval, indigenous parasite fauna. Performing comparative studies between differently managed and not managed herds of horses helps to address proper recommendations for control programs and predict the consequences of inadequate treatment strategies used.

\section{Acknowledgements}

We would like to thank Mr. Ireneusz Masztalerski and Ms. Agnieszka Tylkowska from the BNP for their great help during the study. The authors would like to thank Prof. Eugene T. Lyons and Dr. Sharon C. Tolliver (Department of Veterinary Science, University of Kentucky, Gluck Equine Research Center, USA) for their critical reading of the manuscript. This study was supported partially by scholarship of the Visegrad Fund, Slovakia and ALRAKIS MUNDUS Program.

\section{References}

GAwOR, J. (1995): The prevalence and abundance of internal parasites in working horses autopsied in Poland. Vet. Parasitol., 58, 99 - 108. DOI: 10.1016/0304-4017 (94) 00698-C

HeRd, R.P. (1992): Performing equine fecal egg counts. Vet. Med., 87, 240-244.

Kuzmina, T.A., Kharchenko, V.A., Starovir, A.S., Dvoinos, G.M. (2005): Analysis of the strongylid nematodes (Nematoda: Strongylidae) community after deworming of brood horse in Ukraine. Vet. Parasitol., 131, $283-290$

Kuzmina, T.A., KhaRChenKo, V.A. (2008): Anthelmintic resistance in cyathostomins of brood horses in Ukraine and influence of anthelmintic treatments on strongylid community structure. Vet. Parasi- tol., 154, 277 - 288. DOI: 10.1016/j.vetpar.2008.03.024

Kuzmina, T., Kornaś, S., Basiaga, M., Kharchenko ,V., Vyniarska, A. (2011): Biodiversity of strongylids (Nematoda: Strongylidae) communities in domestic horses from Poland and Ukraine. Helminthologia, 48, 77 - 84. DOI: 10.2478/s11687-011-0013-7

Lichtenfels, J.R., Kharchenko, V.A., Dvojnos, G.M. (2008): Illustrated identification keys to strongylid parasites (Strongylidae: Nematoda) of horses, zebras and asses (Equidae). Vet. Parasitol., 156, 4 - 161. DOI: 10.1016/j.vetpar.2008.04.026

Lyons, E.T., Toluiver, S.C., Collins, S.S., Drudge, J.H., Granstrom, D.E. (1997): Transmission of some species of internal parasites in horses born in 1993, 1994 and 1995 on the same pasture on a farm in central Kentacky. Vet. Parasitol., 70, 225 - 240

Meana, A., Olmeda, A.S., Pato, N.F., Diez, E., Felipe, M., Mota, J. (2004): Prevalence of major parasitic infections in free-ranging horses at Donana (Spain). In: Abstracts of the Proceedings of IX European Multicolloquium of Parasitology, Valencia, Spain, 18 23 July, 2004, 463

Mfitilodze, M.W. And Hutchinson, G.W. (1990): Prevalence and abundance of equine strongyles (Nematoda: Strongyloidea) in tropical Australia. J. Parasitol., 4, 487 - 494

Nielsen, M.K., Vidyashankar, A.N., Olsen, S.N., Monrad, J., ThamsBORG, S.M. (2012): Strongylus vulgaris associated with usage of selective therapy on Danish horse farms - Is it reemerging? Vet. Parasitol., 189, 260 - 266. DOI: 10.1016/j.vetpar.2012.04.039

Osterman Lind, E., Eysker, M., Nilsson, O., Uggla, A., Höglund, J. (2003): Expulsion of small strongyle nematodes (Cyathostomin spp.) following deworming of horses on a stud farm in Sweden. Vet. Parasitol., 115: 289 - 299. DOI: 10.1016/S0304-4017(03)00200-0 Pesenko, Y.A. (1982): Principles and methods of quantitative analysis in faunistic investigations. Moscow: Nauka: 1 - 284 [In Russian] Reinemeyer, C.R., Smith, S.A., Gabel, A.A., Herd, R.P. (1984): The prevalence and intensity of internal parasites of horses in the USA. Vet. Parasitol., 15, 75-83

Shannon, C.E., WeAVER, W. (1949). The mathematical theory of communication. University of Illinois Press, Urbana, 125 pp.

SlivinSKA, K., GAWOR, J., JaWORSKI, Z. (2009): Gastro-intestinal parasites in yearlings of wild Polish primitive horses from the Popielno Forest Reserve, Poland. Helmintologia, 46(1), 9 - 13. DOI: 10.2478/s11687-009-0002-.

SLIVINSKA, K., WRÓBLEWSKI, Z., GAWOR, J. (2013): Occurrence of gastro-intestinal parasites in Polish primitive horses from the Roztocze National Park, Poland. Vestn. Zool., 47(6), 53 -61. DOI: 10.2478/ vZOO-2013-0053

Scialdo-Krecek, R.C., Reinecke, R.K., Biggs, H.C. (1983): Studies on the parasites of zebras III. Nematodes of the Mountain zebra from the farm "Kelpie" and the Namib-Naukluft Park, South West Africa/Namibia. Onderstepoort J. Vet. Res., 50, 283 - 290

Studzińska, M.B., Tomczuk, K., Demkowska-Kutrzepa, M., SzczepaNIAK, K. (2012): The Strongylidae belonging to Strongylus genus in horses from southeastern Poland. Parasitol. Res., 111, 1417 - 1421. DOI: 10.1007/s00436-012-3087-3 